Mondays to Fridays, and 1000-1300 hr. on Saturdays. A vision signal of a suitable test card is provided on a frequency of $194.75 \mathrm{Mc} . / \mathrm{s}$., using a radiated power of about $1 \mathrm{~kW}$. from a temporary mast $85 \mathrm{ft}$. high, using vertically polarized transmission. While both the power and the height of the aerial to be used for the Independent Television Authority's service trans: mitter will be considerably greater than these values, it is considered that the signals obtained over a radius of $10-20$ miles from this test transmitter should be of considerable assistance to all those concerned with the development of television in Band III.

\section{Organization of Agricultural Research}

THE organization of agricultural research in Britain has recently been reviewed by the Government. As a result, the grant-aiding function hitherto exercised by the Ministry of Agriculture, Fisheries and Food has been transferred to the Agricultural Research Council. The financial and general administration, as well as the scientific direction, of the grant-aided agricultural research institutes in England and Wales will therefore be unified under the Council. The independent status of the grant-aided institutes will not be affected. So far as Scotland is concerned, the Government has accepted the recommendation of the Royal Commission on Scottish Affairs and no change will be made in the present arrangements, under which grants-in-aid are made to certain agricultural research institutes by the Secretary of State for Scotland, on the advice of the Agricultural Research Council. The importance of linking agricultural research effectively with the needs of the agricultural industry is fully recognized. To this end an order will be submitted for the approval of Her Majesty in Council, reconstituting the Committee for the Privy Council for Agricultural Research, so as to consist of the Lord President of the Council and the two agricultural Ministers. Close attention will continue to be given to the co-ordination of the work of the Agricultural Research Council on one hand, and the Agricultural Improvement Councils of England and Wales and of Scotland on the other. These changes will, it is hoped, be completed by March 31, 1956.

\section{Peaceful Uses of Atomic Energy: British Exhibi- tions at Geneva}

During the International Conference on the Peaceful Uses of Atomic Energy to be held in Geneva during August (see Nature, April 9, p. 615), there will be an exhibition of equipment, etc. Great Britain will be represented by two collections of exhibits. One will be of a purely scientific character and intended principally for members of delegations. It is being arranged by the United Kingdom Atomic Energy Authority at the Palais des Nations, and will cover an area of 3,000 sq. ft. It will be mainly concerned with nuclear reactors for research and for the generation of power, and with specialized instrumentation which Britain has developed in this field. The second exhibition, in the Palais des Expositions, will be open both to delegations and to the general public. In an area of 5,000 sq. ft., the United Kingdom Atomic Energy Authority exhibits will provide a general survey of the peaceful applications of atomic energy in Britain. The subjects presented will include Britain's first atomic power station, now being built at Calder Hall; the ten-year power station programme; isotope applications in industry, medicine and agriculture; and nucleonics. Associated with this central feature will be exhibits presented by British firms concerned with atomic energy development. To co-ordinate the commercial exhibits, a central committee has been formed, under the chairmanship of Mr. Eric H. Underwood, director of public relations to the Atomic Energy Authority, and including representatives of the Federation of British Industries, the nucleonics industry, civil engineering contractors, boilermakers and manufacturers of electrical and generating equipment. Mr. N. C. Pratt (Philips Electrical, Ltd.) is acting as honorary co-ordinator to the commercial exhibition committee. Inquiries of a technical character should be addressed to Mr. E. H. Underwood at the United Kingdom Atomic Energy Authority, St. Giles Court, 1-13 St. Giles High Street, London, W.C.2.

\section{Research in the Belgian Congo}

An illustrated brocbure has been issued by the Institute for Scientific Research in Central Africa, founded at Leopoldville, Belgian Congo, on July 1, 1947, describing the fumctions and organizations of the Institute and its activities and achievements during its first five years (pp. $14+13$ plates. Brussels : Institut pour la Recherche Scientifique en Afrique Centrale, 1955). Its first task is to encourage studies by research workers in Belgian Central Africa and scientific visitors to the Congo ; but it is also responsible for co-ordinating scientific work in the area and making it more systematic. Up to the end of 1954 the Institute had built up a staff of forty Europeans and four hundred Africans, and a central library at the Lwiro Research Centre, on Lake Kivu, Bukavu, consisting of sixteen thousand volumes. Its three main fields of research are the physical, biological and human sciences. The latter embrace physical and social studies of the African, including his nutrition and physical aptitudes and characteristics, political organization, culture and economy. Physical research is concentrated at Lwiro and Mabali and includes astrophysical, solar radiation, geophysical and seismological studies, while biological work includes human nutrition and zoology at Lwiro, hydrobiology at Uvira, biochemistry at Elizabethville, and physiology and botany at Mbali.

\section{Mount Everest}

To the readers of any of the works on Mount Everest, a pamphlet in the form of a chart entitled "Everest : a Guide to the Climb", by James Champion (London : University of London Press, 1955 ; 1s. 6d.), should be welcome. It portrays the ascent of the mountain from $17,000 \mathrm{ftr}$, indicating the main features of the route and the position of the camps. Mr. Campion has analysed the features of the climb clearly and comprehensively, and so has much increased the reader's appreciation of the almost insurmountable difficulties. The pamphlot also contains two pictorial sketch-maps of the topmost regions of the mountain, and there are short biographical notes on the climbers, including the Sherpas.

\section{Beit Memorial Fellowships for Medical Research}

BErT Memorial Fellowships for Medical Research (junior fellowships worth $£ 800$ a year) have been awarded to the following for research at the institutions indicated: Dr. P. C. Caldwell, the mechanism of muscular contraction in Crustacea (Marine Bio- 